\title{
TEKANAN PEMBENTUKAN RUANG PUBLIK PADA REALITAS SOSIAL BERPOTENSI KONFLIK DI PRIMETIME NEWS METRO TV
}

\author{
Chory Angela Wijayanti* \\ Program Studi Ilmu Komunikasi, Fakultas Ilmu Komunikasi, Universitas Kristen Petra, \\ Jalan Siwalankerto 121-131, Surabaya 60236, INDONESIA \\ * Penulis Korespondensi, email: chory@petra.ac.id
}

\begin{abstract}
ABSTRAK
Demokratisasi media, menciptakan sebuah ruang publik yang menjadi peluang dan jembatan bagi interaksi masyarakat, untuk dapat mengatasi konflik sosial. Namun, karena banyaknya kepentingan yang terlibat, kontruksi realitas sosial di media massa seringkali malah menimbulkan kebencian atau stereotip pada kelompok tertentu yang terlibat dalam konflik. Hal ini semakin terasa saat konflik tersebut melibatkan perempuan yang terkait dengan industri seks, yang ditempatkan sebagai sebuah patologi sosial. Penelitian ini kemudian melihat bagaimana tekanan faktor-faktor dalam media massa terhadap pembentukan ruang publik pada peristiwa penutupan lokalisasi Dolly dan Jarak di Surabaya, sebagai sebuah realitas sosial yang berpotensi konflik tersebut. Melalui metode analisis wacana kritis milik Norman Fairclough, dengan memfokuskan pada dimensi kedua, yaitu praktik wacana (discourse practice), hasil penelitian menunjukkan bahwa faktor-faktor presenter sebagai individu pekerja media, rutinitas media, organisasi media, dan ekstra media, mempengaruhi konstruksi realitas sosial di media massa. Akibatnya, program talk show Primetime News menjadi tidak netral karena pada kenyataannya dikendalikan oleh para aktor media massa, yang mengontrol media massa dengan menduduki akses-akses untuk menseleksi tema, informasi, dan kontribusi.
\end{abstract}

Kata kunci: Media massa, ruang publik, realitas sosial, lokalisasi.

\begin{abstract}
Democratization of the media, creating a public sphere into an opportunity and a bridge for community interaction, in order to resolve social conflicts. However, because of the many interests involved, construction of social reality in the mass media is often creating a negatif stereotype on certain groups that involved in the conflict. Moreover, when the conflict involves a woman associated with the sex industry, which was placed as a social pathology. This research see how the factors in the mass media supress the formation of public sphere in the event of the closing of localization "Dolly and Jarak" in Surabaya, as a social reality which potentially conflict. Research uses Norman Fairclough's critical discourse analysis method, by focusing on a second dimension, discourse practice. The results showed that presenter as individual media workers, media routine, media organizations, and the extra media, influenced the construction of social reality in mass media. As a result, the program talk show Primetime News is not neutral because mass media actors control the mass media by occupying accesses to select a theme, information, and contributions.
\end{abstract}

Keywords: Mass media, public sphere, social reality, localization.

\section{PENDAHULUAN}

Di Indonesia, dalam sepanjang tahun 2013, konflik sosial yang naik 23,7 persen dibanding tahun sebelumnya, telah mengakibatkan 203 orang tewas, 361 orang terluka, 483 rumah dirusak, dan 173 bangunan lainnya dibakar (Tribunnews, 2014). Banyaknya konflik sosial ini muncul sebagai akibat dari lunturnya sistem budaya asli yang tergerus oleh adanya perubahan zaman, akulturasi, dan asimilasi. Hal ini menyebabkan hilangnya rasa saling percaya, komunikasi antar warga, serta melemahnya kohesivitas sosial di dalam masyarakat.
Temuan CSRC Universitas Islam Jakarta menunjukkan bahwa mentalitas toleransi mayoritas adalah toleransi pasif. Salah satu gejala yang terlihat adalah saat masyarakat meletakkan persoalan intoleransi di lingkungannya sebagai masalah internal, bukan urusan publik. Selain itu, toleransi pasif ini menyebabkan semakin rendahnya empati dan kepedulian terhadap persoalan minoritas.

Sejauh ini berbagai upaya untuk mengatasi konflik sosial yang terjadi di Indonesia telah banyak dilakukan, baik oleh pemerintah maupun kalangan sipil. Namun, hal itu belum membuahkan hasil 
memadai mengatasi konflik dan menciptakan perdamaian jangka panjang. Alternatifnya perlu diambil penanganan konflik berbasis pada kelembagaan politik demokrasi yang mampu mengakomodasi kepentingan dan juga pengakuan akan identitas yang ada.

Penciptaan arena publik (public sphere) yang bebas dan demokratisasi arena publik merupakan salah satu jalan untuk mendekatkan negara dan masyarakat sipil dalam berbagai sektor kebijakan publik. Namun, hal ini tidak akan terwujud, saat demokrasi tersebut dibajak dan dipergunakan hanya untuk kepentingan segelintir elite, penguasa, maupun bisnis (Wibowo, 2011, p.73-74).

Oleh karena itulah, diperlukan media massa, yang merupakan entitas paling kuat di dunia. Media memiliki kemampuan mengendalikan pikiran masyarakat melalui informasi dan pengetahuan yang disampaikannya, sehingga gagasan, perilaku, dan kebijakan para pemimpin negara pun, tersampaikan ke masyarakat. Demokratisasi media ini berarti membuka peluang yang luas bagi semua pihak di masyarakat untuk bisa terlibat dalam kegiatan media yang menjadi tempat dan jembatan bagi interaksi masyarakat (seluruh kelompok yaitu pemerintah, pengusaha, partai politik, masyarakat sipil, dan banyak pihak lainnya) untuk membangun kehidupan bermasyarakat, berbangsa, dan bernegara yang lebih baik. Proses demokratisasi media tidak sederhana dan mudah. Proses ini membuka, memberikan peluang sekaligus tantangan (Siregar, 2014, p. xxvii).

Dalam pemberitaan konflik, media massa seringkali mengonstruksi realita sosial sedemikian rupa, sehingga menimbulkan kebencian atau stereotip pada kelompok tertentu yang terlibat dalam konflik. Stereotip yang cukup banyak muncul di media adalah yang berhubungan dengan gender atau jenis kelamin, terutama pada perempuan, yang dikonstruksi sebagai "warganegara kelas dua" (the second class citizen), atau dalam istilah Simone de Beauvoir, The Second Sex (Ibrahim, 2011, p.271).

Ketidakadilan gender dalam media ini semakin terasa saat perempuan dikaitkan dengan industri seks, yang oleh Dr. Kartini Kartono dalam bukunya "Patologi Sosial" (2014, p.v), ditempatkan sebagai salah satu dari lima jenis patologi sosial, bersama dengan perjudian, korupsi, kriminalitas, dan mental disorder. $\mathrm{Hal}$ ini pula yang muncul saat media mengonstruksi penutupan lokalisasi Dolly dan jarak di Surabaya.

Cemi Fitriani Jamal (2013), dalam penelitiannya menyebutkan Dolly sebagai kawasan prostitusi yang telah memiliki kekuatan politik sendiri. Hal ini didasarkan pada berbagai keuntungan yang di hasilkan serta bagaimana setiap pihak di dalam lokalisasi mengatur hidup dan kebijakan mereka sendiri. Selain itu, keikutsertaan peran serta aparat militer yang dari tahun 1980-an, turut memperkuat dan mempengaruhi eksistensi prostitusi Dolly selama ini. Dengan berbagai keuntungan yang dihasilkan Dolly, terutama dari segi ekonomi, membuat banyak pihak memperebutkan wilayah ini.

Demikian banyaknya pihak yang terlibat, menimbulkan kekhawatiran yang besar, akan potensi konflik sosial yang muncul saat pemerintah memutuskan untuk menutup lokalisasi ini. Hal ini menarik perhatian media massa, baik cetak, elektronik, maupun online. Berbagai macam bentuk peliputan dilakukan untuk mengulas permasalahan ini.

Salah satu bentuk tayangan televisi yang disiarkan untuk membahas penutupan lokalisasi Dolly dan Jarak ini secara khusus adalah Primetime News di Metro TV. Program dalam format talk show ini menayangkan liputan dan pembahasan yang mendalam mengenai penutupan lokalisasi Dolly dan Jarak tersebut, dengan menghadirkan beberapa narasumber yang dinilai memiliki keterkaitan dengan isu tersebut.

Dalam penelitian Pratiwi Ambarwati (2005), disebutkan bahwa ruang publik dalam media massa tidak terwujud dalam program acara yang memang sudah "dirancang" untuk tidak menampilkan bentukbentuk partisipasi publik dalam tayangannya. Format tayangan talk show, dinilai memungkinkan untuk memberikan kesempatan bagi partisipasi publik yang lebih besar.

Talk show sendiri, telah dianggap sebagai representasi ruang publik di televisi (Bignell, 2004, p.123), yang di dalamnya isu-isu publik menjadi bahan perdebatan yang rasional, dengan menggunakan pertukaran wacana dan asumsi. Keberadaan debat yang demokratis di dalam talk show menjaga keberlangsungan dari sebuah ruang publik di dalam sebuah masyarakat yang berkembang. Yang menjadi pertanyaan kemudian adalah bagaimanakah faktor-faktor dalam media massa menekan pembentukan ruang publik, terutama pada realitas berpotensi konflik tersebut?

\section{TINJAUAN PUSTAKA}

\subsection{Ruang Publik}

Jurgen Habermas memperkenalkan konsepsi ruang publik, yang terbentuk di antara masyarakat sipil dan negara, sebagai tempat diskusi publik kritis mengenai 
persoalan kepentingan umum, yang dilindungi secara institusional dan berada di dalam konteks historis spesifik dimana ekonomi pasar sedang berkembang (Habermas, 2012, p.viii-ix). Ruang demokratis, tempat warganegara dapat menyatakan opini-opini, kepentingan dan kebutuhan-kebutuhan mereka secara diskursif adalah gagasan pokok ruang publik.

Di dalam kerangka pemikiran Habermas, keberadaan ruang publik politis sebagai kondisi komunikasi, dapat menumbuhkan kekuatan solidaritas yang mengutuhkan sebuah masyarakat dalam perlawanannya terhadap sumber-sumber lain, yakni uang (pasar kapitalis) dan kuasa (birokrasi negara), agar tercapai suatu keseimbangan. Ruang publik lalu dimengerti sebagai ruang otonom yang berbeda dari negara dan pasar, karena tidak hidup dari kekuasaan administratif maupun ekonomi kapitalis, melainkan dari sumbersumbernya sendiri.

Media massa, kemudian memegang peranan penting sebagai ruang publik bagi realitas sosial yang ada di masyarakat. Di dalam ruang publik-lah "pertarungan simbolik" atau "pertarungan wacana" atau sederhananya "pembicaraan" bisa menunjukkan kemurnian "the soul of democracy", sukma demokrasi sari suatu masyarakat politik. Partisipasi penuh masyarakat dalam pembangunan dan pemerintahan dan debat rasional mengenai isu-isu politik dipandang sebagai elemen kunci demokrasi (Ibrahim, 1998, p. xxxix).

Dalam proses demokrasi deliberatif atau pembentukan ruang publik ini, Habermas membayangkan sebuah kondisi pembicaraan yang ideal (ideal speech situation), dimana partisipan bebas untuk mendengarkan, menjelaskan, dan menyampaikan pikiran mereka, tanpa takut akan adanya pembatasan atau kontrol. Dia menyakini bahwa validitas dari setiap konsensus yang beretika, akan dapat diraih hanya jika tiga kebutuhan akan akses (requirement for access), argumentasi (requirement for argument), dan pembenaran (requirement for justification), terpenuhi (Griffin, 2011, p.243).

\subsection{Konstruksi Realitas Sosial}

Realitas sosial, dilihat sebagai hasil konstruksi sosial yang diciptakan oleh individu, dimana kebenarannya bersifat relatif, berlaku sesuai konteks spesifik yang dinilai relevan oleh pelaku sosial. Peter L. Berger dan Thomas Luckmann (1991) menjelaskan lebih lanjut bahwa realitas sosial adalah hasil ciptaan manusia kreatif melalui kekuatan konstruksi sosial terhadap dunia sosial di sekelilingnya.

Konstruksi yang beragam atas realitas sosial ini, tidak jarang menciptakan potensi terjadinya konflik sosial, saat dalam hubungan antara dua pihak atau lebih, terdapat tujuan yang tidak kompatibel (Haryatmoko, 2014, 189). Realitas sosial ini sendiri memiliki makna saat dikonstruksi dan dimaknakan secara subyektif oleh individu lain sehingga memantapkan realitas itu secara obyektif.

Media massa kemudian menjadi salah satu jalan untuk membentuk kontruksi realitas sosial di masyarakat. Dalam struktur komunikasi yang sudah sedemikian rupa, media telah diintervensi oleh berbagai kepentingan, sehingga tidak bisa bebas dari distorsi. Shoemaker (1996, p.64), menyebutkan lima level atau faktor yang mempengaruhi isi media (media content), yaitu (1) Ideologi, (2) Ekstra media, (3) Organisasi, (4) Rutinitas media, dan (5) Individu (pekerja media).

\section{METODE PENELITIAN}

Penelitian ini menggunakan metode penelitian analisis wacana kritis yang akan menghubungkan teks dan konteks untuk melihat tujuan dan praktik bahasa. Pendekatan perubahan sosial akan digunakan sebagai kerangka analisis penelitian ini dengan mengambil pemikiran dari Norman Fairclough, dimana terdapat keterkaitan antara teks (mikro) dengan konteks masyarakat (makro).

Titik perhatian dari metode penelitian ini adalah melihat bahasa sebagai praktik kekuasaan. Metode ini melihat bagaimana pemakai bahasa mengusung nilai ideologis tertentu melalui analisis yang menyeluruh. Bahasa secara sosial dan historis adalah bentuk dari tindakan, dalam hubungannya dengan struktur sosial. Oleh karena itu, analisis memusatkan pada bagaimana bahasa itu terbentuk dan dibentuk dari relasi sosial serta konteks sosial tertentu (Eriyanto, 2001, p.285334).

Fairclough membagi analisis wacana dalam tiga dimensi, yang secara sederhana, kerangka analisisnya tergambar dalam Gambar 1. 


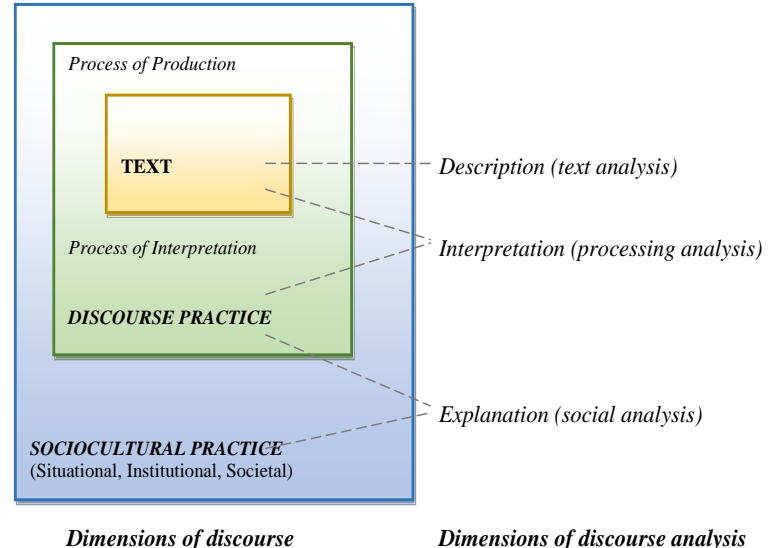

Sumber: Fairclough, 2010, p.133

Gambar 1. Kerangka Analisis Wacana Norman Fairclough

Penelitian ini hanya menggunakan dimensi kedua saja, yaitu praktik wacana (discourse practice). Dimensi ini berhubungan dengan proses produksi dan konsumsi teks. Sebuah teks pada dasarnya dihasilkan lewat praktik diskursus atau proses produksi, seperti pola kerja, bagan kerja, dan rutinitas dalam menghasilkan teks. Demikian pula pola atau proses konsumsi teks dapat berbeda dalam konteks yang berbeda. Konsumsi dapat dihasilkan secara personal atau kolektif. Pada tingkatan discourse practice, untuk mendapatkan informasi mengenai proses produksi wacana dalam talk show Prime Time News, peneliti melakukan wawancara dengan awak redaksi. Datadata yang ditemukan dalam proses wawancara ini kemudian peneliti kaitkan dengan hasil analisis wacana yang telah ada sebelumnya. Selain itu, peneliti juga akan melakukan analisis dengan menggunakan konsep milik Shoemaker dan Reese, yang membahas mengenai faktor-faktor yang mempengaruhi isi media. Faktor-faktor tersebut adalah level individu (pekerja media), rutinitas media, organisasi media, ekstra media, dan ideologi media.

\section{HASIL DAN PEMBAHASAN}

Faktor dalam media mempengaruhi kontruksi realitas sosial berpotensi konflik, yaitu penutupan lokalisasi Dolly dan Jarak di Surabaya, melalui program talk show Primetime News. Pertama, presenter sebagai individu pekerja media, secara efektif mengatur serta mengintegrasikan suara-suara lain yang muncul dalam program tersebut, menentukan kualitas hubungan dengan penonton, serta membentuk bingkai diskursif.

Dengan menggunakan jenis wawancara yang berbeda pada narasumber yang berbeda, presenter berupaya untuk mengendalikan jalannya dialog. Presenter menggunakan jenis The Accountability Interview saat melakukan dialog dengan pemerintah sebagai penentu kebijakan; The Experiental/Witness Interview dengan pelacur sebagai sosok personal yang terkait langsung dalam isu; serta The Expert Interview dengan tokoh sosial atau akademisi untuk menjelaskan latar belakang masalah.

Dengan demikian, struktur berita yang terbentuk lebih bersifat terbuka (open structure news discourse), karena peran presenter lebih bergantung pada jalannya wawancara dengan narasumber. Hal ini memungkinkan presenter untuk berimprovisasi, serta mempertanyakan hal-hal yang muncul dalam dialog langsung. Wacana dalam Primetime News, kemudian terbentuk sebagai berita komprehensif, di mana fakta yang diuraikan merupakan uraian terperinci yang selain memperhatikan segi konteks, juga dikaitkan dengan nilai-nilai yang berlaku di masyarakat.

Presenter juga diposisikan secara tradisional, duduk di belakang meja, dengan pengambilan gambar kamera middle close up, atau dari kepala sampai ke bawah sebatas dada. Dalam posisi seperti ini, terdapat pembatasan ruang sosial antara presenter dan narasumber, sehingga kesan yang muncul adalah kesan formal dan wawancara yang berlangsung tetap dalam tataran profesional.

Faktor rutinitas media, yang berkaitan dengan keseharian dari mekanisme pembentukan berita, juga sangat menentukan isi media. Setiap organisasi media massa memiliki kebijakan pemberitaan dan pengelolaan berita tersendiri yang sudah menjadi ciri khas media tersebut. Kebijakan redaksional tersebut dioperasionalisasikan dalam mekanisme kerja redaksional, mulai dari proses perencanaan berita.

Dalam penelitian ini, yang memegang peranan paling penting di dalam proses produksi program Primetime News, adalah tahapan pra produksi yang memakan porsi $70 \%$ dari keseluruhan acara. Tahapan ini dimulai dengan pembuatan pre-rundown oleh producer dan executive producer, yang berisi rencana isi tayangan. Pre-rundown ini kemudian dibawa ke dalam rapat yang tidak hanya melibatkan tim produksi saja, namun juga termasuk tim news gathering (tim peliputan berita). Tim news gathering ini terdiri atas koordinator daerah, koordinator nusantara, koordinator desk nasional, manajer, dan pimpinan redaksi, jika sedang bisa hadir. Selain itu, dalam rapat juga hadir beberapa perwakilan yang terkait dengan kerja di newsroom, seperti kameraman, editor, grafik, dan sebagainya. 
Rapat ini membahas semua hal yang terkait dengan isu atau topik yang ingin diangkat berdasarkan prerundown yang telah dipersiapkan oleh executive producer sebelumnya. Di dalamnya akan ditentukan angle (sudut) pemberitaan, judul, narasumber, bentuk liputan, dan sebagainya. Dalam penentuan semua detail berita ini, terjadi diskusi untuk membicarakan pre-rundown tadi. Banyak masukan yang dihasilkan, sehingga bukan tidak mungkin bila di ujung diskusi, saat keputusan dihasilkan, pre-rundown yang telah dipersiapkan menjadi benar-benar berubah. Proses diskusi yang sangat menentukan inilah yang membuat tahapan pra produksi ini menjadi tahapan yang memakan porsi paling besar.

Dalam pembuatan keputusan di tahapan ini, Metro TV selalu berpihak pada kepentingan yang lebih banyak, dalam hal ini masyarakat. Meski demikian, Metro TV berusaha menjaga agar tetap berada di tengah, sesuai dengan kaidah jurnalistik, yaitu cover both sides. Pada edisi "Mengubah Wajah Gang Dolly", Metro TV menentukan sikap untuk pro atau mendukung penutupan lokalisasi. Pertimbangan yang digunakan lebih pada alasan moral, dimana terdapat banyak perdagangan manusia di sana. Dengan melihat PSK sebagai korban dari praktik perdagangan manusia tersebut, maka Metro TV menyatakan dukungan terhadap penutupan lokalisasi Dolly dan Jarak. Untuk menjaga cover both sides, Metro TV menekankan pada tanggung jawab pemerintah kota Surabaya untuk memberikan peluang kerja bagi PSK, membuat mereka memiliki kapasitas lain, selain memperdagangkan tubuh mereka sendiri. Dengan demikian, pemilihan angle, alur cerita, narasumber, dan sebagainya, digunakan untuk mendukung sikap ini.

Keberadaan program lain sebagai faktor organisasi media, juga mempengaruhi kebijakan-kebijakan dalam memproduksi tayangan talk show Primetime News di Metro TV, termasuk saat membicarakan mengenai penutupan lokalisasi Dolly dan Jarak di Surabaya.

Dalam proses produksi Primetime News, aspek organisasi yang berperan adalah keberadaan program lain. Ada kebijakan dalam organisasi Metro TV yang mengatur bahwa tidak boleh ada dua program yang membahas satu isu yang sama, dengan sudut dan cara yang sama. Sebagai sebuah stasiun televisi berita (news channel television) yang tayang selama 24 jam sehari, ada pembagian isu pada semua program.

Dalam kasus penutupan lokalisasi Dolly dan Jarak, meskipun sikap utama yang ditentukan adalah persetujuan terhadap penutupan lokalisasi terkait dengan adanya perdagangan manusia di sana, namun Primetime News tidak menekankan penelusuran mengenai bagaimana perdagangan manusia itu terjadi. Hal ini disebabkan karena pendekatan ini telah dilakukan oleh program yang lain.

Edisi "Mengubah Wajah Dolly" tayang tepat pada hari penutupan lokalisasi Dolly dan Jarak, sehingga Primetime News mengambil penelusuran dengan angle yang lain, yaitu tentang bagaimana tanggung jawab pemerintah kota Surabaya untuk memberikan peluang kerja bagi PSK, membuat mereka memiliki kapasitas lain, selain memperdagangkan tubuh mereka sendiri. Dengan demikian, pemilihan angle, alur cerita, narasumber, dan sebagainya, digunakan untuk mendukung sikap ini.

Selain itu, pemilihan narasumber juga dipengaruhi oleh kebijakan tersebut. Misalnya, dalam edisi "Mengubah Wajah Gang Dolly" tersebut, Tri Rismaharini (Risma), Walikota Surabaya, tidak dihadirkan menjadi salah satu narasumber. Padahal, dalam penutupan lokalisasi Dolly dan Jarak ini, pemerintah kota, menjadi pihak utama yang terlibat. Jika mengikuti istilah yang digunakan oleh Metro TV, bisa dikatakan bahwa Risma adalah narasumber kategori "Kelas 1", yang akan memberi nilai lebih pada dialog. Namun pada hari yang sama, Risma ternyata telah menjadi narasumber pada program lain. Sehingga Primetime News kemudian menghadirkan Syaifulah Yusuf (Gus Ipul), Wakil Gubernur Jawa Timur, untuk mewakili pihak pemerintah yang terlibat dalam penutupan tersebut.

Faktor terakhir yang mempengaruhi isi Primetime News adalah faktor ekstra media, adalah faktor yang berasal dari luar lingkungan media yang turut mempengaruhi proses produksi isi media. Penonton menjadi salah satu faktor dari luar yang mempengaruhi isi Primetime News.

Menurut hasil evaluasi atau analisis penonton terhadap tayangan Primetime News, yang menjadi potential viewer (penonton potensial) dari segmentasi di atas adalah laki-laki, dengan usia antara 40-60 tahun. Penonton potensial inilah yang kemudian menjadi penonton setia yang perlu dijaga (maintenance). Karakteristik penonton inilah yang menjadi patokan bagi tim produksi, untuk memberikan bentuk-bentuk tayangan yang sesuai dengan selera mereka, misalnya dalam hal pemilihan presenter yang tepat. Hal ini nampak dalam pernyataan yang disampaikan oleh Catharina dalam wawancara berikut ini: 
Pengaruh dong. Kan kita menjaga loyalitas penonton juga. Pemirsa juga. Kalau laki-laki, kadang-kadang kalau kita kasih anchor dialog tuh, seperti Avi misalnya, Aviani Malik. Karena dia secara mata menarik, secara ngobrol juga asik, gitu kan. Kalau laki-laki dikasih laki-laki lain juga boleh. Tapi laki-lakinya tipenya kayak indra. Gitu misalnya. Karena Indra itu, ngomongin dialog politiknya itu pas banget. Khas mereka, selera-selera mereka lah. Hahaha. Maksudnya kayak gitu lah kurang lebih.

Selain jenis kelamin dan usia, segmentasi penonton utama Metro TV yang aktif dan berwawasan luas, juga mempengaruhi keputusan dalam memilih narasumber. Misalnya dalam edisi "Mengubah Wajah Gang Dolly", salah satu asalan yang membuat Thamrin dipilih sebagai narasumber adalah sosoknya yang dikenal seringkali melontarkan pernyataanpernyataan yang kontroversial. Pada tahun 2010, Thamrin mengeluarkan pernyataan yang dianggap menghina masyarakat dayak, pada saat menjadi saksi ahli dalam proses peradilan kasus video porno yang melibatkan Ariel, di Pengadilan Negeri Bandung.

Pada 30 Maret 2012, dalam dialog interaktif di program 8-11 Show Metro TV, Thamrin menyebut Susilo Bambang Yudhoyono, yang saat itu menjabat sebagai Presiden Republik Indonesia, seperti tomcat. Terakhir, pada Jumat 28 Juni 2013, dalam acara talk show Apa Kabar Indonesia (AKI) Pagi di TvOne, Munarman, Thamrin disiram teh oleh Juru Bicara Front Pembela Islam (FPI). Sebagai sosok yang mungkin tidak bisa diterima banyak pihak, menghadirkan sosok seperti Thamrin ini, justru menjadi sarana untuk bisa menghidupkan dialog, karena menyampaikan sudut pandang lain dalam dialog.

\section{KESIMPULAN}

Peneltian ini menyimpulkan bahwa beberapa faktor dalam media memberikan tekanan dalam mempengaruhi kontruksi realitas sosial penutupan lokalisasi Dolly dan Jarak di Surabaya melalui program talk show Primetime News. Faktor-faktor tersebut antara lain, presenter sebagai individu pekerja media, rutinitas media, organisasi media, dan ekstra media.

Hasil penelitian ini menunjukkan bahwa sebagai medium presentasi ruang publik, Primetime News menjadi tidak netral, karena pada kenyataannya, program ini dikendalikan oleh para aktor media massa. Mereka mengontrol media massa dengan menduduki akses-akses untuk menseleksi tema, informasi, dan kontribusi. Padahal, para pekerja media menjadi individu yang seharusnya bisa menduduki peran-peran sebagai aktor ruang publik ini.

Kemampuan mereka dalam mengendalikan konstruksi realitas sosial di media massa, bisa digunakan untuk memperjuangkan hak-hak publik, terutama dalam masyarakat multikultural yang memiliki keragaman kepentingan. Pekerja media, misalnya presenter, seharusnya dapat membangun sebuah diskursus inklusif di dalam dialog, melalui beberapa narasumber sebagai representasi publik.

Kondisi pembicaraan ideal (ideal speech situation) inilah yang akan membentuk sebuah ruang publik ideal, sesuai dengan rumusan Jurgen Habermas, dimana tiga kebutuhan partisipan, yaitu kebutuhan akan akses, kebutuhan akan argumentasi, dan kebutuhan akan pembenaran, telah terpenuhi. Dengan demikian, dalam penanganan realitas sosial yang berpotensi menimbulkan konflik di Indonesia, pemerintah ataupun pihak lain yang terkait, dapat memanfaatkan keberadaan media sebagai ruang publik, tempat dialog atau diskursus bagi semua pihak yang terlibat, untuk membahas dan menentukan kebijakan-kebijakan yang meniminalisir atau mencegah terjadinya konflik, serta bernilai positif bagi terwujudnya perdamaian di Indonesia.

\section{DAFTAR PUSTAKA}

Ambarwati, Pratiwi. (2005). Televisi dan Ruang Publik: Kajian Kritis terhadap Fungsi RCTI sebagai Ruang Publik. Unpublished postgraduate thesis, Universitas Indonesia.

Berger, Peter L., \& Thomas Luckmann. (1991). The Social Construction of Reality: A Treatise in The Sociology of Knowledge. USA: Penguin Books.

Bignell, Jonathan. (2004). An Introduction to Television Studies. New York: Routledge.

Eriyanto. (2001). Analisis Wacana: Pengantar Analisis Teks Media. Yogyakarta: LkiS Yogyakarta

Griffin, EM. (2011). A First Look at Communication Theory (8th edition). New York: McGraw-Hill.

Habermas, Jurgen. (2012). Ruang Publik: Sebuah Kajian tentang Kategori Masyarakat Borjuis. Bantul: Kreasi Wacana.

Haryatmoko. (2014). Etika Politik dan Kekuasaan. Jakarta: PT. Kompas Media Nusantara

Ibrahim, Idi Subandy, \& Suranto, Hanif (Eds.). (1998). Wanita dan Media: Konstruksi Ideologi Gender dalam Ruang Publik Orde Baru. Bandung: PT. Remaja Rosdakarya. 
Kartono, Kartini. (2014). Patologi Sosial (Jilid I). Jakarta : Rajawali Pres.

Jamal, Cemi Fitriani. (2013). Politik Prostitusi Kota Surabaya (Studi Deskriptif: Eksistensi Dolly). Junal Politik Muda, Universitas Airlangga. Vol 2 no. 1 .

Shoemaker, Pamela J., \& Stephen D. Reese. (1996). Mediating the Message: Theories of Influences on Mass Media Content (Second Edition). USA: Longman Publisher.
Siregar, Amir Effendi. (2014). Mengawal Demokratisasi Media: Menolak Konsentrasi, Membangun Keberagaman. Jakarta: PT. Kompas Media Nusantara.

Wibowo, I. (2011). Negara dan Bandit Demokrasi. Jakarta: PT. Kompas Media Nusantara.

Widianto, Willy. (2014, January 02). IPW: Waspadai Konflik Sosial Tahun 2014. Retreived October 10, 2014, from http://www.tribunnews.com/ nasional/2014/01/02/ipw-waspadai-konfliksosial-tahun-2014. 